\title{
NEW DISTRIBUTION RECORD OF LYSIMACHIA OTOPHORA C.Y.WU (PRIMULACEAE) FROM VIETNAM
}

\author{
Tran Duc Binh ${ }^{1 *}$, Bui Hong Quang1, Do Van Hai ${ }^{1}$, Nguyen Quang Hung ${ }^{1}$, Le Ngoc Han ${ }^{1}$, \\ Vu Anh Thuong ${ }^{1}$, Nguyen Thu Thuy ${ }^{1,2}$ \\ ${ }^{l}$ Institute of Ecology and Biological Resources - Vietnam Academy of Science and Technology \\ ${ }^{2}$ International Biological Material Research Center - Korea Research Institute of Bioscience and Biotechnology
}

\begin{tabular}{|c|c|}
\hline ARTICLE INFO & \multirow{12}{*}{$\begin{array}{l}\text { The occurrence of Lysimachia otophora C.Y.Wu was doubtful in } \\
\text { Vietnam due to the unavailability of related specimens and literature. } \\
\text { In the course of fieldwork in Bat Xat Nature reserve of Lao Cai } \\
\text { province, a distinct species of Lysimachia with a petiole leaf } \\
\text { auriculate at base, racemes axillary, bracts narrowly lanceolate, } \\
\text { corolla yellow and stamens } 5 \text { (with } 2 \text { stamens short and } 3 \text { stamens } \\
\text { long) was found. After careful comparison of our specimens and the } \\
\text { research samples of } L \text {. otophora C.Y.Wu, we concluded that they are } \\
\text { similar. This species has been reported native to China (Yunnan and } \\
\text { Guangxi) until now and reported for the first time in Vietnam. In this } \\
\text { paper, we confirm the new distribution of L. otophora C.Y. Wu in } \\
\text { Vietnam providing suitable references. However, we provided data on } \\
\text { taxonomy, morphology, ecology and distribution of the mentioned } \\
\text { species accompanied by the photographs. Therefore, the total number } \\
\text { of species in this genus is } 23 \text { species and } 1 \text { variety in Vietnam. }\end{array}$} \\
\hline Received: $29 / 6 / 2021$ & \\
\hline Revised: $14 / 9 / 2021$ & \\
\hline Published: $16 / 9 / 2021$ & \\
\hline & \\
\hline KEYWORDS & \\
\hline Lysimachia & \\
\hline New distribution & \\
\hline Bat Xat Nature Reserve & \\
\hline Lao Cai & \\
\hline Viet Nam & \\
\hline & \\
\hline
\end{tabular}

\section{BỔ SUNG VÙNG PHÂN BỐ MỚI CHO LOÀI LYSIMACHIA OTOPHORA C.Y.WU (PRIMULACEAE) Ở VIẸT NAM}

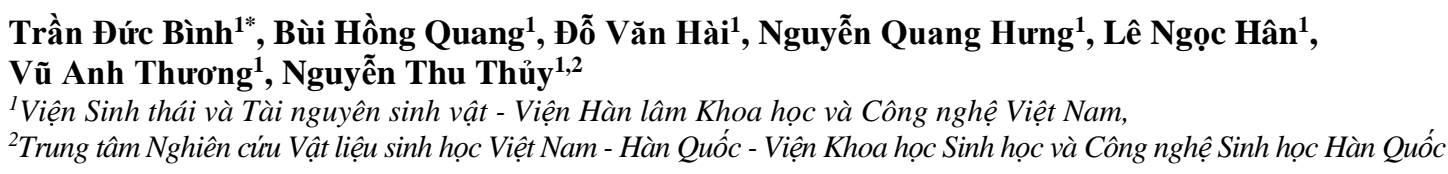

\begin{tabular}{|c|c|}
\hline THÔNG TIN BÀI BÁO & \multirow{11}{*}{ 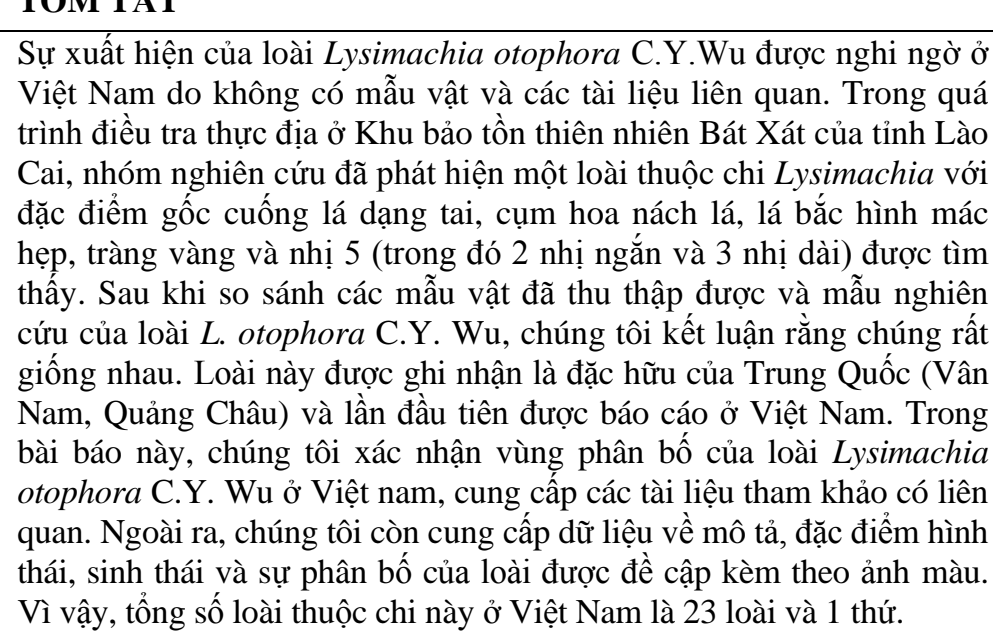 } \\
\hline Ngày nhận bài: 29/6/2021 & \\
\hline Ngày hoàn thiện: 14/9/2021 & \\
\hline Ngày đăng: 16/9/2021 & \\
\hline & \\
\hline TÙ̀ KHÓA & \\
\hline Lysimachia & \\
\hline Phân bố mới & \\
\hline Khu bảo tồn thiên nhiên Bát Xát & \\
\hline Lào Cai & \\
\hline Việt Nam & \\
\hline
\end{tabular}

DOI: $\underline{\text { https://doi.org/10.34238/tnu-jst.4713 }}$

\footnotetext{
*Corresponding author. Email: tranbinha4@gmail.com
} 


\section{Introduction}

The genus Lysimachia L. includes about 140-200 species and was originally placed in Primulaceae [1], mainly distributed in the temperate and subtropical parts of the northern hemisphere, but has a few species in Africa, Australia and South America [2-6].

While studying of the literature, we found that the species Lysimachia otophora has been recorded available in Vietnam [7]. However, the distribution location and study specimen are not specified. Currently, there occur 22 species and 1 variety of Lysimachia are reported in Vietnam [8], [9]-[15].

In 2019-2020, during a plant survey of Bat Xat Nature Reserve in Lao Cai province, we discovered Lysimachia otophora. After carefully studying the monographs, collected specimens and consulting relevant literature [6], [8], [9]-[15], we confirmed the species Lysimachia otophora new distribution in Vietnam; the current specimens have been kept in herbaria (HN) of the Institute of Ecology and Biological Resources. In this paper, we provided the photographs, ecology, distribution, data on taxonomy and notes to easily identify species in future studies.

\section{Methods/Materials}

Materials: Specimens of Lysimachia housed in the herbaria (HN, HNU, P, K, WUK, IBSC, LBG, NAS, HITBC, IMDY, KUN, PE, IBK) were examined, and relevant literatures were also consulted [8]-[10]. Morphological comparison of our specimen with allied species was carried out to confirm the identity of the plant.

Methods: The morphological comparison method was used to study the plants. It is one of the most suitable methods in plant taxonomic studies. Based on the morphological characteristics of the reproductive organs of plants for comparison because it is little change and less affected by the environment [16]. In addition, morphological descriptions were formed on literatures of [7][10]. Besides, the scientific name was updated according to the current latest classification system [17] - [19].

\section{Results and Discussion}

\subsection{Results}

Taxonomic treatment

Lysimachia otophora C.Y.Wu (Figure 1)

C. Y. Wu in C. Y. Wu \& H. W. Li, 1965. Yunnan Redai Yaredai Zhiwu Quxi Yanjiu Baogao (Rep. Stud. Pl. Trop. Subtrop. Yunnan). 1: 46.

Herbs perennial, $20-60 \mathrm{~cm}$ tall, rust-colored strigillose throughout. Stems erect, nearly terete in the lower part, obtusely quadrangular in the upper part, simple or weakly branched. Leaves opposite; petiole 1-3 cm, auriculate and semi-clasping at base; leaf blade elliptic-ovate, 3-7.5 $\times$ 1.5-4 cm, base broadly cuneate to subrounded, apex acute; veins 4-6 pairs, slightly raised abaxially; veinlets invisible. Racemes axillary, 4-10-flowered; peduncle 1-4 cm; bracts narrowly lanceolate, 5-11 mm, outside glabrous, inside ciliate, \pm adnate to base of pedicel. Pedicel 2-5 $\mathrm{mm}$. Calyx 5, Calyx lobes lanceolate, $5-10 \times 1.5 \mathrm{~mm}$, both surfaces puberulent, costate. Corolla yellow, slightly longer than calyx; tube ca. $1 \mathrm{~mm}$; lobes 6-8 $\times 3-4 \mathrm{~mm}$, sparsely transparent glandular, apex acute. Stamens 5; with 2 stamens short and 3 stamens long; filaments connate basally into a 2-2.3 mm high tube, glandular, free parts 2-4.5 $\mathrm{mm}$; anthers yellow, oblong, dorsifixed, opening by lateral slits, ca. $1 \mathrm{~mm}$. Pistil $8 \mathrm{~mm}$; ovary ca. $2 \mathrm{~mm}$, sparsely strigillose of $2 / 3$ upper part, glabrous of $1 / 3$ lower part; style $4-6 \mathrm{~mm}$, sparsely puberulent at the base, stigma glabrous. Capsule greenish when young, subglobose, ca. $3 \mathrm{~mm}$ in diam.

Loc. class.: China Type: Not found yet

Flowering and fruiting: May-July. 
Ecology and habitat: Lysimachia otophora found in Bat Xat Nature Reserve, near the border of China. We are observed at Red waterfall, $7 \mathrm{~km}$ SSE of Y Ty village. This species was found growing on slopes, secondary forest, along streams, wet places, at elev. about $1400 \mathrm{~m}$. About in association with Gnetum montanum, Uncaria sp., Symplocos sp., Hartia sp., Asarum petelotii, Vaccinium sp., Anemone sumatrana, Burmannia disticha.

Distribution: China (Yunnan, Guangxi), Vietnam (Lao Cai province, Bat Xat district, Y Ty commune). (Figure 2)

Specimens examined: CHINA. Yunnan: June 1934, H. T. Tsai 62371 (WUK: WUK 0045635 Photo!, 0045605 Photo!; IBSC: IBSC 0004649 Photo!; LBG: LBG 00098149 Photo!; NAS: NAS 00047606 Photo!); 17 may 1936, alt. 1530 m, C.W. Wang 73657 (WUK: WUK 0045954 Photo!, 0045954 Photo!; IBSC: IBSC 0004648 Photo!; LBG: LBG 00098148 Photo!; NAS: NAS 00047604 Photo!); 29 March 1940, alt. 700 m, C.W. Wang 89683 (WUK: WUK 0268496 Photo!, 0268496 Photo!; HITBC: HITBC 042694 Photo!); 20 June 1934, alt. 1100 m, H. T. Tsai 60365 (LBG: LBG 00098144 Photo!); 31 may 1934, H. T. Tsai 62016 (LBG: LBG 00098145 Photo!); 23 may 1934, alt. 1300 m, H. T. Tsai 55394 (LBG: LBG 00098146 Photo!); 13 July 1934, alt. 1300 m, H. T. Tsai 60853 (LBG: LBG 00098147 Photo!; NAS: NAS 00047605 Photo!); 28 April 2012, alt. 1122 m, 5325230340 (IMDY: IMDY 001936 Photo!); Pingbian, Daweishan Mt, N.N.R, Shuiweicheng, N 22 ${ }^{\circ}$ 54' 45.72"; E 103 42' 03.51"; alt. 2047 m, 25 may 2014, Cai J, Ta J.D, Yu X.Q, Su Y, Li C.H. 14CS9205 (KUN: KUN 1395836 Photo!, 1395837 Photo!); Jinping County, Fenshuiling Natural Reserve, Adebo, alt. 1400 m, 27 June 2009, Yunnan Expedition Team, YN-ET 209 (PE: PE 01895522); Pingbian County, Baihe, Mabuchong, Dachengziqing, alt. 1400 m, 02 July 2009, Yunnan Expedition Team, YN-ET 635 (PE: PE 01895523 Photo!), 07 June 1974, alt. 1200 m, 1581 (PE: PE 00204792 Photo!); Guangxi: 07 may 1957, 32259, (IBK: IBK 00028413 Photo!); 21 September 1977, 3-43342, (GXMI: GXMI 038359 Photo!, 038358 Photo!), 03 June 2009, alt. 800 m, 09528 (IBK: IBK 00280878 Photo!).

VIETNAM, Lao Cai province, Bat Xat district, Y Ty commune, Bat Xat Nature Reservce, N $22^{\circ}$ 36' 17,1"; E $103^{\circ} 38^{\prime}$ 44,8"; alt. 1445 m, 30 July 2019, Bui Hong Quang, Tran Duc Binh, VN-RU 179 (HN); Bat Xat Nature Reservce, N 22 36' 09,1"; E 103 38' 51,4" alt. 1416 m, 15 August 2020, Bui Hong Quang, Le Ngoc Han, Vu Anh Thuong, Tran Duc Binh, BHQ 163 (HN); Bat Xat Nature Reservce, N 22 36' 09,1”; E 103 38' 51,4" alt. 1416 m, 15 August 2020, Vu Anh Thuong, VAT 15052020-2 (HN).

Notes: According to our observations, Lysimachia otophora is common in the Red waterfall of Y Ty municipality in Bat Xat Nature Reserve. This is different from the rest of Lysimachia in Vietnam by having leaves opposite (vs. alternate or connate at base), inflorescence racemes axillary less than 10 flowered (vs. flowers solitary or racemes terminal more than 10 flowered). Besides, Lysimachia otophora is similar to Lysimachia congestiflora by leaves opposite, inflorescence racemes, leaf blade elliptic-ovate. However, Lysimachia otophora is distinguished from L. congestiflora by followed characteristics (Table 1).

Table 1. Comparison of diagnostic characters of L. otophora and L. congestiflor

Morphological Character

\begin{tabular}{ll}
\hline Stem & rust-colored strigillose throughout \\
Petiole leaves & auriculate and semi-clasping at base \\
Side leaf & $3-7.5 \times 1.5-4 \mathrm{~cm}$ \\
Veins & $4-6$ pairs \\
Inflorescence & Racemes axillary, 4-10 flowered \\
Pedicel & $2-5 \mathrm{~mm}$ \\
\hline
\end{tabular}

\section{L. congestiflora}

fulvous pilose

narrowly winged

$1.4-3(-4.5) \times 1.3-2.2(-3) \mathrm{cm}$

2-4 pairs

Racemes terminal, 2-4 flowered to $2 \mathrm{~mm}$ 


\subsection{Discussion}

Lysimachia otophora has been reported native to China at an altitude from 1100 to $2047 \mathrm{~m}$ in Yunnan and $800 \mathrm{~m}$ in Guangxi, which are near Lao Cai province (Bat Xat district). When we investigated in the field, we found this species with a similar altitude of about $1450 \mathrm{~m}$. We predict that at a similar altitude to its occurrence in Vietnam and probably should be expected elsewhere.

\section{Conclusion}

The morphological characteristics of Lysimachia otophora C.Y. Wu have been described, with information on distribution, research samples, color photos, maps. Our research for the first time reports the occurrence of Lysimachia otophora in Vietnam. Therefore, the total number of species in this genus is 23 species and 1 variety.

\section{Acknowledgment}

We are grateful to Chi-Ming Hu (South China Botanical Garden, Chinese Academy of Sciences) for encouragements. This research was funded by IDEA WILD in 2020-2021 and the Vietnam Academy of Science and Technology (VAST) (project No. VAST 04.03/20-21).

\section{REFERENCES}

[1] P. F. Stevens, "Angiosperm Phylogeny Website. Version 14", 2017, (last updated: 05/22/2021). [Online]. Available: http://www.mobot.org/MOBOT/research/APweb/. [Accessed 18 Aug. 2021].

[2] D. J. Mabberley, Mabberley's Plant-book: a portable dictionary of plants, their classification and uses. Cambridge: Cambridge University Press, 2008.

[3] B. Ståhl and A. A. Anderberg, "Myrsinaceae," inThe families and genera of vascular plants 6, Kubitzki K, ed. Berlin: Springer, 2004, pp. 266-281.

[4] V. H. Heywood, R. K. Brummitt, A. Culham, and O. Seberg, Flowering Plant Families of the World. Kew, England: Royal Botanic Gardens, 2007.

[5] R. Z. Fang, "Primulaceae," in Flora Yunnanica 15, Wu, C. Y., Ed., Sci. Press, Beijing, 2003, pp. 326514,

[6] H. Chi-Ming, "Further Notes on the Genus Lysimachia L. in Mainland S. E. Asia," Acta Phytotaxonomica Sinica, vol. 5, no. 23, pp. 355-368, 1985.

[7] C. M. Hu and S. Kelso, "Primulaceae," in Flora of China, Z. Y. Wu and P. H. Raven, Eds., vol 15, Science Press, Beijing \& Missouri Botanical Garden Press, St Louis, 1996, pp. 39-189.

[8] C. M. Hu, "Primulaceae," in Flore du Cambodge du Laos et du Viêtnam, P. Morat ed., vol. 26, Muséum national d'Histoire naturell, Paris, 1992, pp. 115-144.

[9] P. H. Ho, An Illustrated Flora of Vietnam, Vol. 1. Youth Publishing House, Mekong, 991 pp., 1991.

[10] N. T. Ban (Ed.), Checklist of plant species of Vietnam, vol. 2, Agricultural Publishing House, (in Vietnamese), Hanoi, , 2005, pp. 513-516.

[11] M. D. Zhang, Y. M. Shui, W. H. Chen, and Z. D. Wei, "Lysimachia gesneroides (Myrsinaceae), a new species from Yunan and Vietnam.” Annales Botanici Fennici, no. 43, pp. 317-319, 2006.

[12] K. L. Phan and C. M. Hu, "Lysimachia vietnamensis and L. verbascifolia spp. nov. (Primulaceae) from Vietnam," Nordic Journal of Botany, vol. 29, pp. 601-604, 2011, doi: 10.1111/j.17561051.2011.01174.x

[13] Y.-H. Tong, N.-H. Xia and L. V. Lam, "Lysimachia rupestris F. H. Chen \& C. M. Hu (Primulaceae): a new record for the flora of Vietnam and reconsideration of its taxonomical position," Adansonia, sér. 3, vol. 39, no. 2, pp. 125-128, 2017, doi: 10.5252/a2017n2a3.

[14] B. H. Quang, T. T. Bach, E. Sangmi, D. V. Hai, N. S. Khang, L. N. Han, T. D. Binh, N. T. Thuy, V. A. Thuong, N. K. Trung, C. Ya-Ping, P. W. Fritsch, H. Chi-Ming, L. T. Ngan, J. A. N. Parnell, A. N. Sennikov, J. R. I. Wood, Yi Yang, A. N. Kuznetsov, S. P. Kuznetsova, and M. S. Nuraliev, "Towards a floristic inventory of Bat Xat Nature Reserve, Vietnam: Thirteen new national records of vascular plants," Wulfenia, no. 27, pp. 233-250, 2020. 
[15] L. V. Averyanov, K. S. Nguyen, T. H. Tran, A. L. Averyanova, T. V. Maisak, and H. T. Nguyen, Plant diversity, flora and vegetation of Bat Dai Son Mountain area, northern Vietnam, SaintPetersburg, STRATA, 561 pp., 2020.

[16] N. N. Thin, Plant research methods. Hanoi National University Publishing House, (in Vienamese), Hanoi, 2007.

[17] WFO, "World Flora Online," 2021. [Online]. Available: http://worldfloraonline.org/ [Accessed 18 Aug. 2021].

[18] Board of Trustees of the Royal Botanic Gardens, Kew, "Plants of the World Online," 2021. [Online]. Available: http://plantsoftheworldonline.org/ [Accessed 18 Aug. 2021].

[19] WCSP, "World Checklist of Selected Plant Families," 2021. [Online]. Available: https://wcsp.science.kew.org/ [Accessed 18 Aug. 2021].

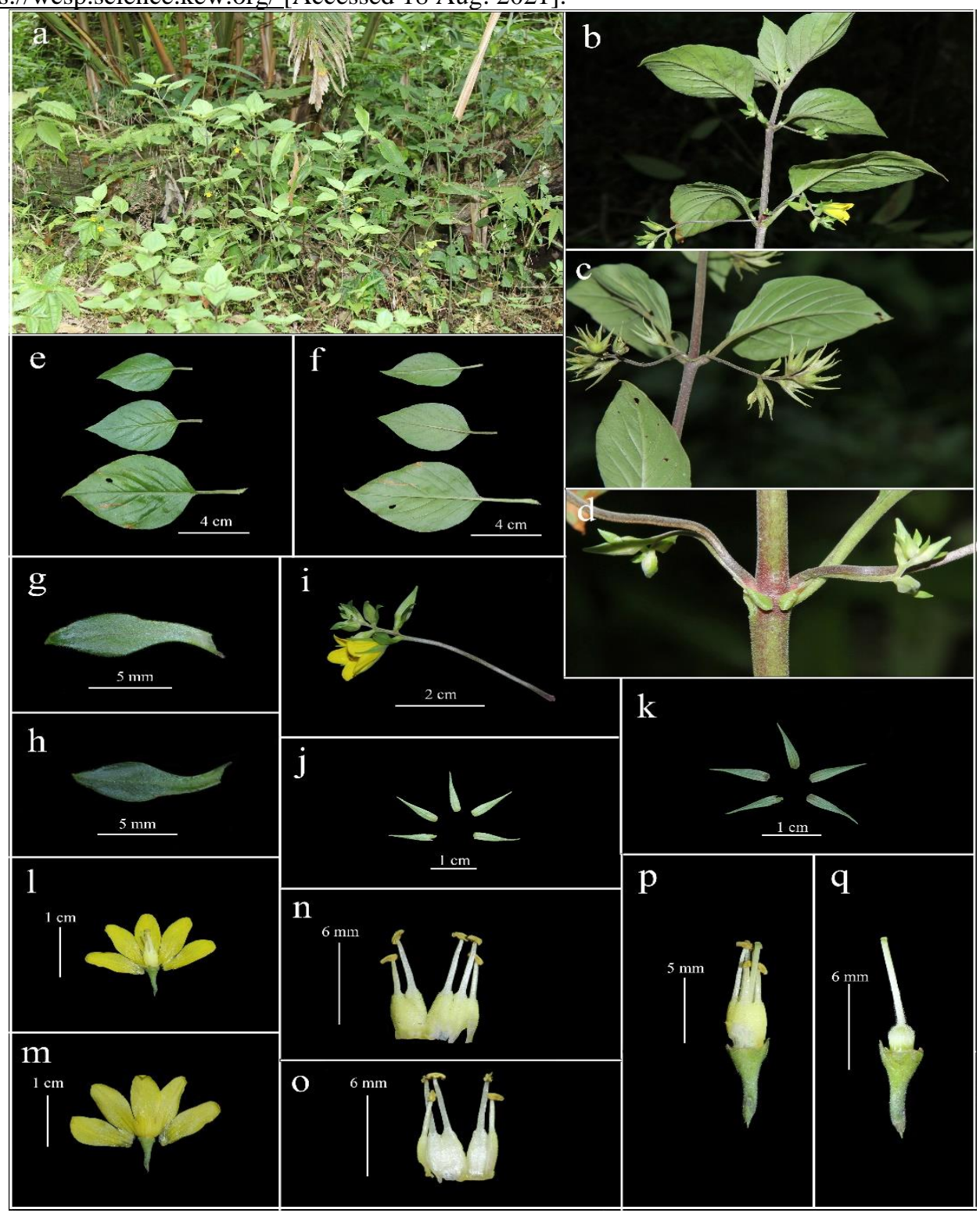

Figure 1. Lysimachia otophora C.Y.Wu

a- Habitat; $b$-Plant in flowering; $c$ - Plant in fruit; $d$-petiole; $e$ - Adaxial leaf; $f$-Abaxial leaf; $g$ - Bracts inside views; $h$-Bracts outside views; $i$-Flowers; $j$-Calyx outside viewrs; $k$-Calyx inside views; $l$-Flower, lateral view; $m$ - Flower, back view; $n$-Stamens outside; o-Stamens inside; $p$-Stamens and Pistil; q-Pistil (Photos by T. D. Binh) 


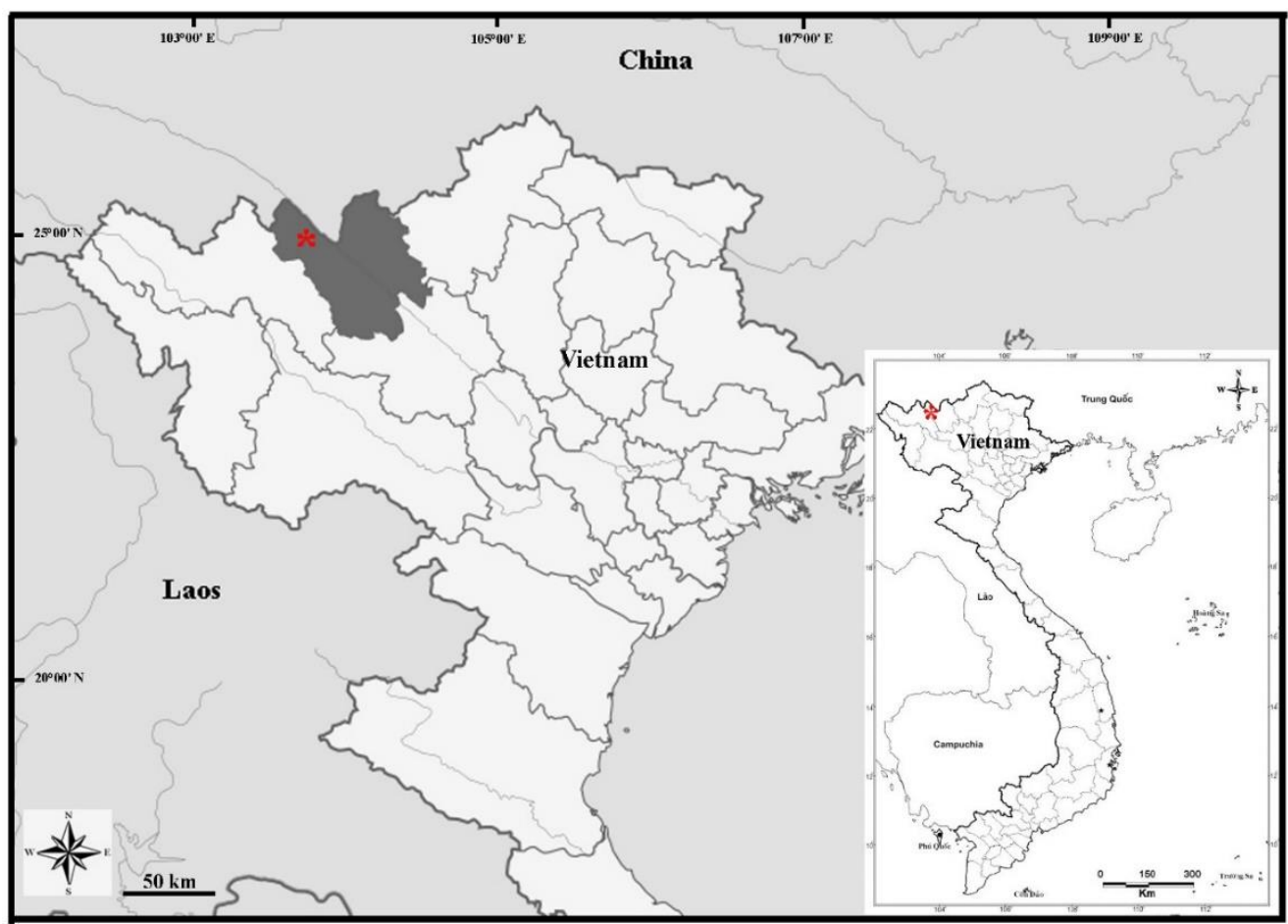

Figure 2. The distribution of Lysimachia otophora C.Y.Wu in Vietnam 